\title{
A REGIÃO DO PARQUE ESPINILHO E A BACIA HIDROGRÁFICA DO RIO QUARAÍ, SEGUNDO O INVENTÁRIO FLORESTAL CONTÍNUO DO RIO GRANDE DO SUL ${ }^{1}$
}

\author{
JOSÉ NEWTON CARDOSO MARCHIORI² FABIANO DA SILVA ALVES ${ }^{3}$
}

\section{RESUMO}

São criticamente analisados os textos relativos à Região do Parque Espinilho e à Bacia Hidrográfica do rio Quaraí, constantes no Inventário Florestal Contínuo do Rio Grande do Sul. Como resultado, demonstra-se que o texto e os dados apresentados não correspondem à realidade vegetacional encontrada na região.

Palavras-chave: Aspidosperma quebrachoblanco, Bacia hidrográfica do rio Quaraí, Inventário Florestal Contínuo, Parque Espinilho, Prosopis affinis, Prosopis nigra, Rio Grande do Sul.

\begin{abstract}
[The Espinilho Parkland Region and the Quarai River Hydrographical Basin, according to the Continuous Forest Inventory of Rio Grande do Sul State, Brazil].

In this paper, the texts related to the Espinilho Parkland Region and the Quarai River Hydrographical Basin contained in the Continuous Forest Inventory of Rio Grande do Sul State, Brazil, are critically analyzed. As a result, both texts and numerical data do not correspond to the reality of the vegetation found in the region. Key words: Aspidosperma quebrachoblanco, Continuous Forest Inventory, Espinilho Parkland Region, Prosopis affinis, Prosopis nigra, Quaraí River Hydrographical Basin, Rio Grande do Sul State.
\end{abstract}

\section{INTRODUÇÃO}

Indispensável para a avaliação do setor florestal de um país, de uma região ou de uma empresa, o Inventário Florestal não é prática de fácil definição, devido à abrangência de seu escopo e múltiplos objetivos. Mesmo assim, Péllico Netto \& Brena (1997) desempenharamse com sucesso nesta tarefa, uma vez que a fórmula por eles apresentada alia as virtudes de ser sucinta e precisa: "Inventário Florestal é uma atividade que visa a obter informações qualitativas e quantitativas dos recursos florestais existentes em uma área pré-especificada" ${ }^{4}$.

$\mathrm{Na}$ impossibilidade prática da realização de um censo ou enumeração completa de uma ve-

${ }^{1}$ Recebido em 13-5-2011 e aceito para publicação em 15-7-2011.

2 Engenheiro Florestal, Dr. Professor Titular do Departamento de Ciências Florestais, Universidade Federal de Santa Maria. Bolsista de Produtividade em Pesquisa (CNPq - Brasil).

Biólogo, MSc. Professor da Universidade da Região da Campanha (URCAMP-Alegrete). Doutorando do Programa de Pós-Graduação em Engenharia Florestal, UFSM.

4 PÉLLICO NETO, S.; BRENA, D.A. Inventário Florestal. Curitiba: Editorado pelo autores, 1997. p. 6. getação, a questão da amostragem assume fundamental importância em inventários florestais, pois se deve resguardar a garantia de que a amostra seja representativa da população. As amostras, em outras palavras, "com exceção de pequenas discrepâncias inerentes à aleatoriedade presente no processo de amostragem", devem "possuir as mesmas características básicas da população" que representam ${ }^{5}$.

É sob este princípio de Estatística, ciência norteadora do Inventário Florestal, que se passa, na seqüência, ao exame do texto relativo à "Região do Parque Espinilho", constante no "Relatório Final do Inventário Florestal Contínuo do Rio Grande do Sul".

\section{CONSIDERAÇÕES PRELIMINARES}

Publicado em 2001, o "Inventário Florestal Contínuo do Rio Grande do Sul” é a mais recente investigação desta natureza para o conjunto do Estado, motivo pelo qual constitui referência para estudos florestais e da vegetação em geral. O seu "Relatório Final", obra de fôle-

\footnotetext{
5 PÉLLICO NETO \& BRENA, 1997. Op. cit., p. 16.
} 
$\mathrm{go}^{6}$, trata separadamente cada uma das unidades reconhecidas no estado sulino. A "Região do Parque Espinilho", tema a ser inicialmente examinado, consta, fundamentalmente, entre as páginas 266 e 274 do referido relatório.

Antes da abordagem do texto convém tecer, ao menos, um breve comentário sobre a designação de "Parque Espinilho", escolhida por seus autores.

É bem verdade que o termo, apesar de equivocado, vingou na literatura sul-rio-grandense e ganhou foro legal com a criação do "Parque Estadual do Espinilho" ${ }^{7}$, unidade de conservação que visa a preservar o fragmento mais representativo dos parques de inhanduvá no Estado. O termo, embora oficial para a referida unidade de conservação, mostra-se inadequado à vegetação em análise, uma vez que o espinilho (Vachellia caven (Molina) Siegler \& Ebinger) não é, sabidamente, a sua espécie característi$\mathrm{ca}^{8}$.

De ampla dispersão nas áreas campestres do Rio Grande do Sul, o espinilho apresenta "seus primeiros vestígios" na altura da linha que liga "Bagé, Cruz Alta, Barra do Ijuí, Rio Uruguai", segundo palavras de Balduíno Rambo , autor original do referido equívoco terminológico que teima em persistir na literatura fitogeográfica regional. De fato: parques com espinilhos (Vachellia caven) ocorrem em diversas regiões do Rio Grande do Sul, inclusive no Planalto

6 Compõe-se de 706 páginas, em dois volumes.

7 Criado em 12/3/1975, pelo Decreto n 23.798 do Governo do Estado do Rio Grande do Sul. Sua área original, de 276 hectares, foi ampliada para 1.617,14 hectares em 28/2/2002, mediante o Decreto $n^{\circ} 41.440$ do Governo do Estado do Rio Grande do Sul.

8 As unidades de vegetação costumam ser designadas com base na presença ou ausência de espécies características. A Floresta Ombrófila Mista, por exemplo, é também conhecida - e de modo apropriado - como "Floresta com Araucária" ou "Mata com Araucária", entre outros termos de uso regional. Para a vegetação em análise, portanto, vê-se que o termo "Parque de Inhanduvá" é o mais adequado, por ser esta, justamente, a sua espécie característica.

9 RAMBO, B. A fisionomia do Rio Grande do Sul. Porto Alegre: Livraria Selbach, 1956. p. 130.
Médio, onde se encontra a localidade de "Espinilho Grande", mas também na Depressão Central, na Serra do Sudeste e, com abundância, nos solos rasos do Planalto da Campanha, onde a espécie chega a ser um dos elementos mais conspícuos na paisagem.

Sabe-se, desde sempre, que a espécie mais característica na singularidade vegetacional de Barra do Quaraí é o inhanduvá (Prosopis affinis), e não o espinilho (Vachellia caven). Esta confusão só existe na literatura e em documentos oficiais, pois a população local distingue perfeitamente as duas espécies e sabe que é o inhanduvá a mais importante e característica na região ${ }^{10}$. Para maiores esclarecimentos sobre 0 tema, o leitor interessado pode consultar um artigo dos mesmos autores do presente traba1 ho ${ }^{11}$, dedicado, integralmente, à abordagem fitogeográfica dos parques de inhanduvá no Rio Grande do Sul e à análise de pendências terminológicas correlatas.

Cabe frisar que estes comentários iniciais não são ociosos, pois os graves equívocos a serem apontados, na sequiência, derivam, em boa parte, da fragilidade conceitual acerca do que são, verdadeiramente, os parques de inhanduvá do Pontal do Quaraî́12.

${ }^{10}$ O equívoco originou-se, provavelmente, dos nomes comuns atribuídos por Rambo às espécies integrantes do parque: o atual Prosopis affinis foi por ele chamado de "algarrobo" e Vachellia caven de "inhanduvâ̂"; o termo "espinilho", curiosamente, não foi usado por Rambo para nenhuma espécie em particular. A este respeito, Galvani (2003) e Galvani \& Baptista (2003) especularam que o termo "Parque Espinilho", cunhado por Rambo, em vez de aludir à Vachellia caven, estaria ligado ao "tipo de formação vegetal ocorrente na denominada Provincia do Espinhal", de Cabrera (1951). Sobre este último ponto, Marchiori \& Alves (2010) demonstraram que esta hipótese carece de fundamento, pois a primeira edição de "A Fisionomia do Rio Grande do Sul" data de 1942, antecedendo em nove anos, portanto, a primeira descrição da "Província do Espinal", realizada por Angel Lulio Cabrera somente em 1951.

${ }^{11}$ MARCHIORI, J.N.C.; ALVES, F. da S. O Inhanduvá (Prosopis affinis Spreng.) no Rio Grande do Sul. 1 Embasamento fitogeográfico e pendências terminológicas. Balduinia, Santa Maria, n. 24, p. 1-11, 2010.

${ }^{12}$ Criado por Justus et al. (1986), o termo "Pontal do 
Outros pontos denotativos do escasso conhecimento teórico que norteou o planejamento, a execução e a redação final do relatório produzido sobre a "Região do Parque Espinilho" se pode constatar, com toda a clareza, já no capítulo dedicado ao referencial bibliográfico sobre a vegetação em estudo ${ }^{13}$.

Entre outras impropriedades, o documento em análise informa que o relevo "dominantemente aplainado" na "Região do Parque Espinilho" se encontra "entalhado em derrame basáltico" ${ }^{14}$, um crasso equívoco, uma vez que é bem sabido que a geomorfologia é de natureza muito distinta em todo o Pontal do Quaraí, composta de areias, cascalheiros e sedimentos síltico-argilosos, configurando uma típica planície de inundação. Do outro lado do rio Uruguai (margem direita), a formação sedimentar se estende ao largo da Mesopotâmia argentina e avança pelo Chaco adentro, até a proximidade das Serras de Córdoba, pelo menos. Sobre este ponto, aliás, cabe salientar que o inhanduvá é espécie ecologicamente associada a formações sedimentares, motivo pelo qual o Planalto da Campanha ${ }^{15}$, adjacente ao Pontal, funcionou como eficiente barreira para a dispersão natural da espécie em área mais ampla, no oeste do Rio Grande do Sul. Uma análise mais detalhada deste ponto, todavia, será retomada mais adiante.

De mais graves conseqüências para a execução do inventário na "Região do Parque Espinilho" foi a leitura pouco criteriosa do referencial teórico disponível na época, caso contrário o resultado poderia ter sido muito diferente - e mais proveitoso -, certamente, do que o alcançado no "Relatório Final".

Quaraí" designa a área aplanada e de natureza sedimentar, situada entre os rios Quaraí e Uruguai, próximo a suas confluências.

${ }^{13}$ Páginas 80 e 81, do "Relatório Final do Inventário Florestal Contínuo do Rio Grande do Sul".

${ }^{14}$ Página 80, do mesmo relatório.

${ }^{15}$ O Planalto da Campanha é formado por rochas efusivas básicas (basalto, segundo o documento em análise) da Formação Serra Geral.
A existência de duas realidades vegetacionais nos parques de Barra do Quaraí é conhecida desde 1985, ano em que vieram à luz, em trabalhos separados, as descrições de duas tipologias distintas na região.

No primeiro deles, intitulado "Composição florística e estrutura do Parque de Inhanduvá no Rio Grande do Sul" ${ }^{16}$, foi investigada a vegetação mais encontradiça no Pontal do Quaraí, a mesma, justamente, que fora originalmente descrita por Balduíno Rambo em sua clássica obra: a associação composta, basicamente, pelo inhanduvá e espinilho (Figura 1). Cabe salientar que este tipo de parque é conhecido nos países do Prata pelo nome de Ñandubaysal, correspondendo a "Parque de Inhanduvá", em bom português. Não custa acrescentar que os agrupamentos de Vachellia caven são popularmente ditos Espinillares ${ }^{17}$, tanto no Uruguai como na Argentina.

Em artigo separado, posto que seus autores reconheceram-na como unidade distinta, foi descrita a "Estrutura fitossociológica de uma associação natural de Parque Inhanduvá com Quebracho e Cina-cina", ${ }^{18}$ artigo com diversas novidades importantes para a flora e fitogeografia da região. Trata-se da primeira citação sobre a ocorrência natural do quebracho (Aspidosperma quebrachoblanco Schltdl.) no Rio Grande do Sul (Figura 2) e da primeira descrição, no Estado, de uma associação bem conhecida no Uruguai e Argentina como Algarrobal $^{19}$.

${ }^{16}$ MARCHIORI, J.N.C.; LONGHI, S.J.; GALVÃO, L. Composição e estrutura do Parque de Inhanduvá no Rio Grande do Sul. Rev. Centro de Ciências Rurais, Santa Maria, v. 15, n. 4, p. 319-334, 1985a.

${ }^{17}$ PAZ, E.A.; BASSAGODA, M.J. Aspectos fitogeográficos e diversidad biológica de las formaciones boscosas del Uruguay. Ciência \& Ambiente, Santa Maria, n. 24, p. 39, 2002.

${ }^{18}$ MARCHIORI, J.N.C.; LONGHI, S.J.; GALVÃO, L. Estrutura fitossociológica de uma associação natural de Parque Inhanduvá com quebracho e cina-cina, no Rio Grande do Sul. Ciência e Natura, Santa Maria, n. 7 , p. 147-162, 1985b.

${ }^{19}$ Entre diversas obras: PAZ \& BASSAGODA, 2002. Op. cit., p. 42. 


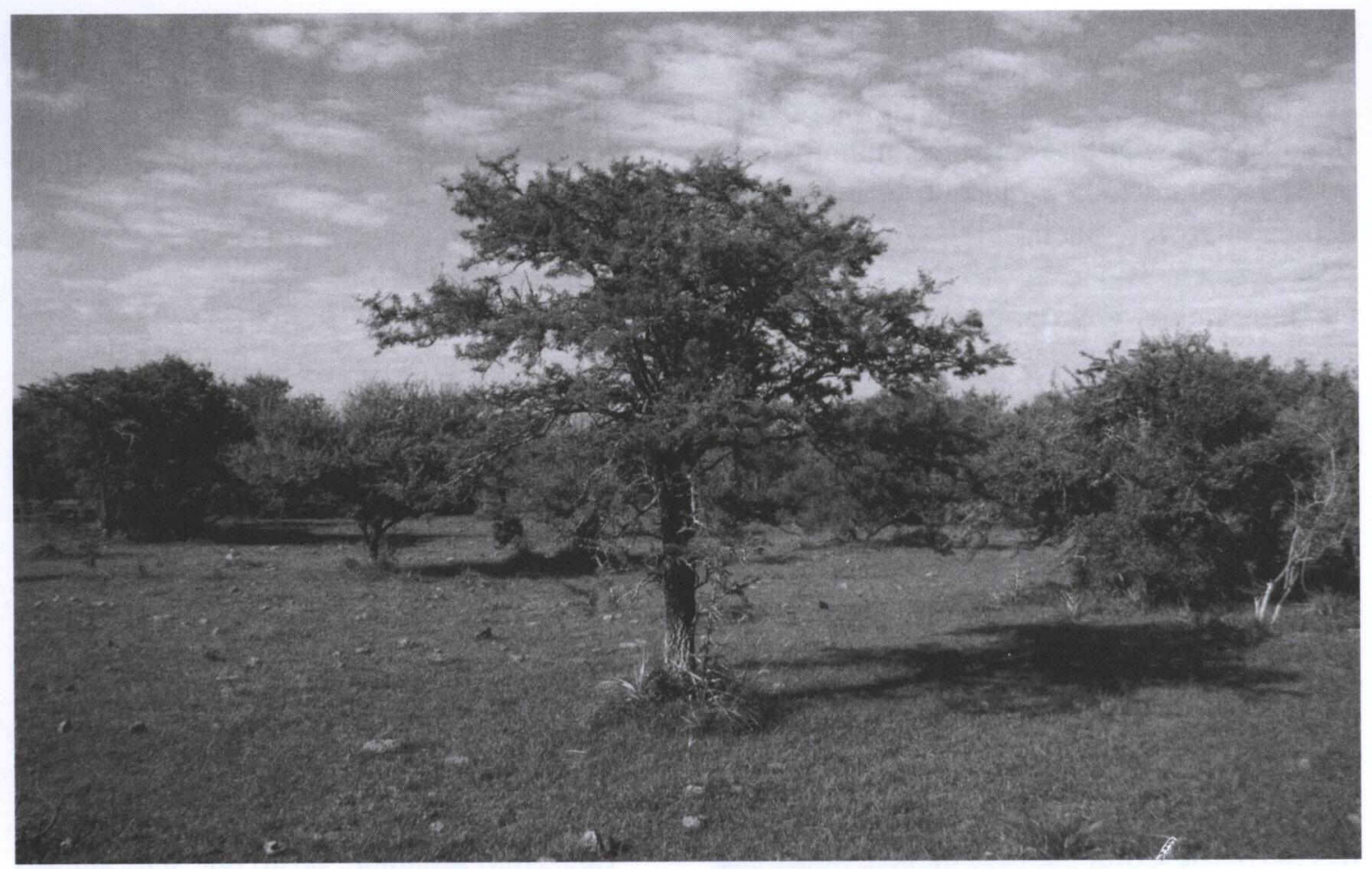

FIGURA 1 - Aspecto do Parque de Inhanduvá descrito por Balduíno Rambo, composto, basicamente, por indivíduos de Prosopis affinis e Vachellia caven.

Feitas estas considerações iniciais, pode-se passar, com melhor embasamento, ao exame do texto produzido sobre a "Região do Parque Espinilho", no "Relatório Final do Inventário Florestal Contínuo do Rio Grande do Sul".

\section{ANÁLISE CRÍTICA DO DOCUMENTO}

Como visto anteriormente, o texto relativo ao Inventário na "Região do Parque Espinilho" consta entre as páginas 266 e 274 do "Relatório Final", incluindo informações gerais, tabelas e análise de dados relativos à composição florística, parâmetros dendrométricos, produção quantitativa por espécie e hectare, qualidade do tronco, sanidade, classe de copa, tendência de valorização, posição sociológica, análise das estruturas horizontal e vertical, regeneração natural e análise estatística de alguns "estimadores para o volume comercial com casca". É este texto, em suma, o objeto central do presente estudo.
Bem no início, fica-se sabendo que a "formação do Parque Espinilho” ocupa área de 22,89 $\mathrm{km}^{2}$ (2.289 ha) em seus estágios "iniciais, médios e avançados", correspondendo a $0,01 \%$ da superfície do Rio Grande do Sul e 0,05\% da área total com florestas naturais no Estado ${ }^{20}$. É sobre estes valores de área, em outras palavras, que se aplicam os resultados penosamente obtidos a campo.

Do parágrafo acima, causa estranheza considerar-se a vegetação em foco como parte integrante das "florestas naturais do Estado". É bem verdade que no "Parque Espinilho" existem verdadeiras árvores - e de distintas espécies -, mas sua estrutura fitossociológica, de caráter savânico, não se encaixa, com toda a certeza, no conceito de floresta. Não custa lembrar, sobre este ponto, que a presença de árvores é uma constante nos campos sul-rio-grandenses, como

\footnotetext{
${ }^{20}$ Página 266, do dito "Relatório Final".
} 


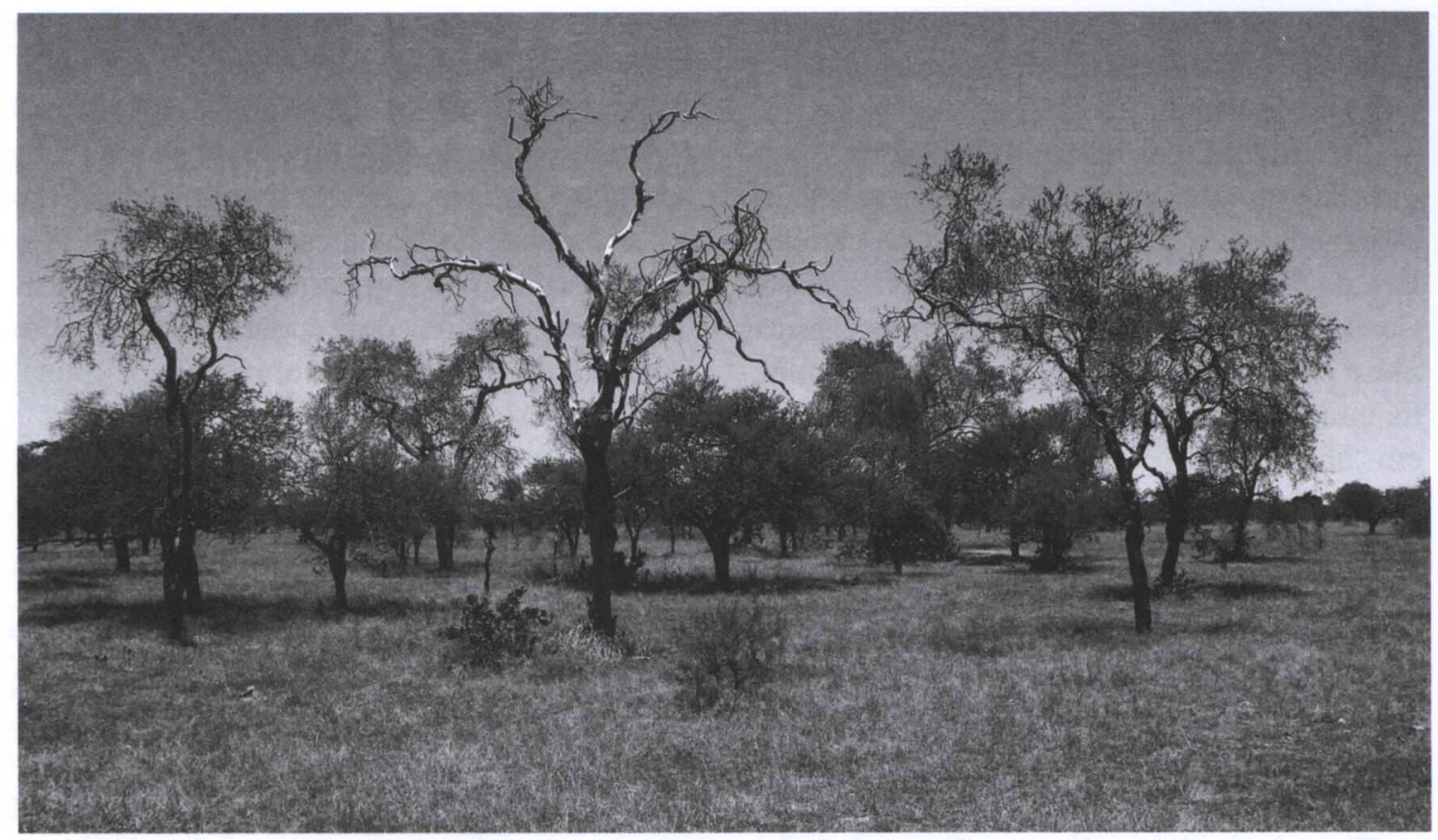

FIGURA 2 - Parque de Inhanduvá, com Prosopis nigra, Prosopis affinis, Vachellia caven e Aspidosperma quebrachoblanco (árvores maiores).

já salientado por Carl Axel Magnus Lindman ao final do século dezenove ${ }^{21}$, em obra de permanente valor científico:

\begin{abstract}
“(...) os campos do Rio Grande, pelo que pude ver, nunca são exclusivamente campos arbustivos, prados, pastagens, gramados, estepes ou, em outros termos, nunca são completamente destituídos de árvores. Seria certamente difícil encontrar uma só milha quadrada em que não entrasse na paisagem um grupo de árvores ou uma parte florestal" ${ }^{22}$.
\end{abstract}

De natureza factual, o lapso acima apontado leva, obviamente, à tomada de decisões equivocadas quando se desconhece esta realidade, sobretudo em levantamentos de vegetação, caso do documento em análise, submetendo-a ao conhecido molde dos inventários florestais.

Mais importante, ainda, mas igualmente derivada desta concepção estranha à realidade, é

${ }^{21}$ A edição original, em sueco, foi publicada em 1900.

${ }^{22}$ LINDMAN, C.A.M. A vegetação no Rio Grande do Sul (Brasil Austral). Porto Alegre: Echenique, 1906. p. 115. o reconhecimento na dita "Região do Parque Espinilho" de dois estágios sucessionais: médio e avançado; e inicial. Tal classificação, bem conhecida e fundamentada na realidade das florestas propriamente ditas ${ }^{23}$, mostra-se de duvidosa utilidade no caso em foco, como demonstra, aliás, com toda a clareza, o texto relativo ao "Estágio Sucessional Inicial", merecedor de transcrição integral, na sequiência, até mesmo por sua constrangedora exigüidade:

"Este tipo fitogeográfico é uma formação típica de parque que ocorre em uma área restrita do Estado, onde não foi (sic) encontrado estágios iniciais de sucessão". ${ }^{24}$

Além do evidente nonsense e erro de concordância logrados em curta frase ${ }^{25}$, cabe

${ }^{23}$ Por exemplo: capoeirinha, capoeira, floresta secundária, clímax florestal, entre outros.

${ }^{24}$ Relatório Final (Op. cit., p. 274).

${ }^{25} \mathrm{O}$ texto informa, literalmente, que o "Estágio Sucessional Inicial" ocorre "em área restrita do Estado", mas, justamente, "onde não foi (sic) encontrado estágios iniciais de sucessão". 
perguntar-se o que seriam os ditos "estágios iniciais" do Parque Espinilho, ocorrentes em "área restrita" do Estado.

Seriam eles, por acaso, os verdadeiros parques de espinilhos (Vachellia caven), vegetação observada, com freqüência, em áreas campestres do Planalto Médio, Missões, Depressão Central, Serra do Sudeste, Planalto da Campanha e alhures? A hipótese carece de fundamento, uma vez que esta vegetação não se encontra em "área restrita".

Estaria o texto remetendo, então, ao parque de inhanduvá propriamente dito (Ñandubaysal), composto basicamente de inhanduvás e espinilhos (sem a presença do algarrobo e quebracho, entre outras espécies), tipologia amplamente predominante no Pontal do Quaraí? A alternativa também não se sustenta, e pelo mesmo motivo ${ }^{26}$.

De todo modo, nenhuma informação o leitor encontrará, mesmo nas entrelinhas do "Relatório Final". Ambas as alternativas acima comentadas, bem como outras tantas que se poderiam aventar, permitem qualquer especulação minimamente fundamentada sobre a que entidade os autores se referem. Seria este, então, precisamente, o motivo pelo qual o escriba remete o "estágio sucessional inicial" do "Parque Espinilho" a "uma área restrita do Estado"? Em caso positivo, fica-se sem saber, de todo modo, onde se encontra tal misteriosa área.

Como corolário do acima exposto ${ }^{27}$, podese concluir que a "Região do Parque Espinilho",

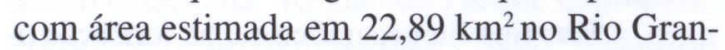
de do Sul, apresenta-se, fundamentalmente, nos estágios sucessionais médio e avançado. É sobre esta área, portanto, ou superfície muito aproximada deste valor, à qual se aplicam os dados

\footnotetext{
${ }^{26}$ O Ñandubaysal não ocorre em área restrita no Pontal do Quaraí; ao contrário, é a tipologia amplamente predominante nos parques da região.

${ }^{27}$ Como afirmado no "Relatório Final", o "estágio sucessional inicial" ocorre em "área restrita"; o Parque Espinilho, por consequiência, deveria compor-se, fundamentalmente, dos "estágios médio e avançado" da vegetação em foco.
}

numéricos constantes no inventário da "Região do Parque Espinilho".

A primeira tabela apresentada no texto informa o número de árvores por hectare para cada uma das espécies, a respectiva área basal e o volume comercial das mesmas, em $\mathrm{m}^{3} / \mathrm{ha}$ (Tabela 1). Tratam-se, em verdade, de dados bási$\cos$, muito esclarecedores sobre a composição florística do estrato arbóreo, motivo pelo qual ela merece ser reproduzida fielmente.

Como se pode ver na referida Tabela, a espécie mais encontradiça na "Região do Parque Espinilho" é Prosopis nigra, que responde, sozinha, por 34,13\% das árvores, seguida, de longe, por Acacia caven (22,68\%), Prosopis affinis $(19,22 \%)$, Parkinsonia aculeata $(11,88 \%)$ e Aspidosperma quebrachoblanco (3,24\%). De Prosopis nigra, o documento em análise informa que ocorrem 63,2 árvores por hectare, um número assombroso, como se verá a seguir.

Se estes dados elementares, obtidos com sabido esforço em trabalhos de campo, constituem uma aproximação, sequer, da realidade, o "Relatório Final" em análise teria trazido uma novidade retumbante no campo científico, pois contradiz toda a literatura existente.

Balduíno Rambo, autor do equivocado nome e da primeira descrição conhecida do "Parque Espinilho", assim o define:

\section{"São principalmente duas espécies de leguminosas arborescentes que determinam o aspecto curioso destes parques espinhosos e secos: o algarrobo (Prosopis algarobilla), e o nhanduvaí (Acacia farnesiana)" ${ }^{28}$.}

Botânico de reconhecida competência, Balduíno Rambo não cometeria deslize com nomes genéricos: é nos nomes vulgares que residem os lapsos flagrantes. Com o tempo, Prosopis algarobilla passou à sinonímia de Prosopis affinis, binômio atualmente válido, e a dita Acacia farnesiana, sabe-se hoje, trata-se,

\footnotetext{
${ }^{28}$ RAMBO, 1956. Op. cit., p. 130
} 
TABELA 1 - Distribuição dos quantitativos biométricos para 11 espécies encontradas e árvores mortas, na vegetação arbórea do Parque Espinilho.

\begin{tabular}{|c|c|c|c|c|c|c|}
\hline \multirow{3}{*}{$\begin{array}{l}\text { Espécie } \\
\text { Prosopis nigra }\end{array}$} & \multirow{2}{*}{\multicolumn{2}{|c|}{$\begin{array}{l}\text { Vol. Comercial } \\
\left(\mathbf{m}^{3} / \mathrm{ha}\right) \quad \%\end{array}$}} & \multicolumn{2}{|c|}{ No Árvores } & \multicolumn{2}{|c|}{ Área Basal } \\
\hline & & & $\left(\mathbf{N}^{\circ} / \mathrm{ha}\right)$ & $\%$ & $\left(\mathrm{~m}^{2} / \mathrm{ha}\right)$ & \multirow{2}{*}{$\begin{array}{c}\% \\
36,23\end{array}$} \\
\hline & 6,23 & 34,16 & 63,2 & 34,13 & 1,50 & \\
\hline Prosopis affinis & 4,01 & 21,98 & 35,6 & 19,22 & 0,93 & 22,46 \\
\hline Acacia caven & 2,35 & 12,88 & 42,0 & 22,68 & 0,50 & 12,08 \\
\hline Parkinsonia aculeata & 2,18 & 11,95 & 22,0 & 11,88 & 0,48 & 11,59 \\
\hline Aspidosperma quebrachoblanco & 1,29 & 7,07 & 6,0 & 3,24 & 0,27 & 6,52 \\
\hline Erythrina cristagalli & 1,01 & 5,54 & 4,0 & 2,16 & 0,23 & 5,56 \\
\hline Scutia buxifolia & 0,68 & 3,73 & 8,4 & 4,54 & 0,14 & 3,38 \\
\hline Mortas & 0,30 & 1,64 & 1,0 & 0,54 & 0,05 & 1,21 \\
\hline Myrcia sp. & 0,13 & 0,71 & 2,2 & 1,19 & 0,03 & 0,72 \\
\hline Myrcianthes cisplatensis & 0,03 & 0,16 & 0,4 & 0,22 & 0,01 & 0,24 \\
\hline Lithraea molleoides & 0,02 & 0,11 & 0,2 & 0,11 & 0,00 & 0,00 \\
\hline Pouteria salicifolia & 0,01 & 0,05 & 0,2 & 0,11 & 0,00 & 0,00 \\
\hline Sub-total & 18,24 & 100,00 & 185,2 & 100,00 & 4,14 & 100,00 \\
\hline Restantes & 0,00 & 0,00 & 0,0 & 0,00 & 0,00 & 0,00 \\
\hline TOTAL & 18,24 & 100,00 & 185,2 & 100,00 & 4,14 & 100,00 \\
\hline
\end{tabular}

Fonte: RIO GRANDE DO SUL, 2001. Op. cit., p. 268.

em verdade, de Vachellia caven, uma vez que Acacia caven recaiu à sinonímia.

Quanto a Rambo chamar de "algarrobo" ao atual Prosopis affinis não merece maiores comentários, uma vez que o termo popular é tradicionalmente usado para diversas espécies argentinas do gênero Prosopis, inclusive para Prosopis affinis, embora mais raramente ${ }^{29}$. Digno de reparo, isto sim, é o termo "nhanduvaî",

${ }^{29}$ IZAGUIRRE \& BEYAHUT (2003) incluem o termo algarrobo entre os nomes populares de Prosopis affinis; para o Brasil (Rio Grande do Sul), entretanto, as autoras referem apenas o nome popular de "inhanduvá". atribuído por Rambo a uma Acacia (atual Vachellia), posto que este nome popular se aplica a Prosopis affinis, exclusivamente, fato amplamente comprovado no restante da literatura botânica, bem como no linguajar regional.

Esclarecida a confusão terminológica feita por Balduíno Rambo, compreende-se, finalmente, a associação originalmente descrita pelo grande botânico gaúcho: uma vegetação com estrutura de parque, formada, basicamente, por inhanduvás (Prosopis affinis) e espinilhos (Vachellia caven). Como dito anteriormente, esta tipologia é a mais abundante na área do "Parque Estadual do Espinilho" e corresponde ao 
Ñandubaysal dos vizinhos argentinos e uruguaios. Junto a estas duas espécies encontram-se outras plantas lenhosas na vegetação em foco, mas não o quebracho (Aspidosperma quebrachoblanco), nem o algarrobo (Prosopis nigra).

Embora bem conhecida pelos habitantes da região, foi somente em 1983 que apareceu a primeira citação na literatura ${ }^{30}$ sobre a ocorrência natural de Prosopis nigra em Barra do Quaraî $^{31}$. Como conceber-se, então, ser esta espécie a mais encontradiça na região, como afirmado (ou demonstrado) no "Inventário Florestal Contínuo"? A que se poderia atribuir tal disparate?

É bem verdade que o algarrobo e o inhanduvá são morfologicamente parecidos, embora perfeitamente distintos em exame mais cuidadoso. Para os barrenses ${ }^{32}$ do campo não existe confusão: o inhanduvá é árvore reconhecidamente valiosa pela durabilidade natural de sua madeira, ao passo que o algarrobo é usado, sabidamente, apenas para lenha e carvão $0^{33}$.

Embora pouco provável, não se pode descartar, completamente, a hipótese de alguma confusão na identidade botânica das espécies de Prosopis em trabalhos de campo, pois eventuais equívocos desta natureza não são tão raros assim, mesmo em inventários que denotam esmero.

Prosseguindo-se no exame da mesma tabela, vê-se que o número de indivíduos de quebracho (Aspidosperma quebrachoblanco) é extraordinariamente alto (6 árvores/ha) para uma árvore

${ }^{30}$ MARCHIORI, LONGHI \& GALVÃO, 1983. Op. cit., p. 174-175. Publicado em 30 de dezembro do mesmo ano, o "Projeto Madeira do Rio Grande do Sul" também incluiu Prosopis nigra entre as Leguminosae nativas no Rio Grande do Sul (REITZ, R.; KLEIN, R.M.; REIS, A. Projeto Madeira do Rio Grande do Sul. Sellowia, Itajaí, 1983. p. 40).

${ }^{31}$ Distrito de Uruguaiana, na época.

${ }^{32}$ Cidadãos do município de Barra do Quaraí.

${ }^{33} \mathrm{Na}$ região do Chaco, sobretudo no norte chaquenho (províncias de Santiago del Estero e Chaco), os indivíduos de Prosopis nigra produzem troncos suficientemente avantajados para o desdobro, motivo pelo qual a espécie adquire considerável importância econômica. Não é este o caso, entretanto, de Barra do Quaraí. sabidamente escassa na região e cuja presença, em solo gaúcho, só foi revelada em $1985^{34}$.

Não é necessário gastar-se o tempo e o esforço despendidos nos trabalhos de campo que deram origem ao "Relatório Final do Inventário Florestal Contínuo do Rio Grande do Sul" para lamentar, com todas as letras, que os dados acima expostos, se não fantasiosos, não se aproximam, sequer, da realidade que pretendem representar. Basta uma rápida circulada pelo "Parque Estadual do Espinilho" para se confirmar, visualmente, esta verdade: o quebracho é elemento escasso e ecologicamente limitado a manchas de pequena extensão, no conjunto do parque. A pesquisa bibliográfica, embora limitada, também ajuda a esclarecer este ponto.

Em tese de doutorado sobre o "Parque Estadual do Espinilho", Galvani (2003) encontrou apenas 17 indivíduos de quebracho, num total de 584 árvores levantadas ${ }^{35}$. Prosopis affinis, com 294 árvores, mostrou-se a espécie com maiores valores de dominância relativa $(63,9)$, densidade relativa $(50,3)$ e freqüência relativa $(35,7)$, seguida por Vachellia caven ${ }^{36}$ (173 árvores levantadas) e Prosopis nigra (52 indivíduos). Até mesmo o garupá (Aloysia gratissima), arbusto lenhoso ou modesta arvoreta, figura no trabalho de Galvani com maior número de indivíduos (20), além de índices mais elevados de densidade relativa $(2,8)$ e freqüência relativa $(3,1)$, comparativamente ao quebracho $(17 ; 1,6$; e 0,7 , respectivamente). A Apocinácea apenas supera o dito garupá no tocante à dominância relativa $(2,3 \times 0,6)$, de acordo com o criterioso inventário de Francisco Renato Galvani. A que se poderia atribuir, então, os disparatados valores constantes no dito "Relatório Final"?

\footnotetext{
${ }^{34}$ REITZ, KLEIN \& REIS (1983) não incluíram Aspidosperma quebrachoblanco entre as Apocináceas nativas no Rio Grande do Sul. A ocorrência natural da espécie no Estado (Barra do Quaraí) foi somente publicada em 1985 (MARCHIORI, LONGHI \& GALVÃO, 1985b).

${ }^{35}$ Corresponde a uma freqüência relativa de apenas $0,7 \%$.

${ }^{36}$ Acacia caven, no texto, pois naquela época o espinilho ainda não havia sido transferido para o gênero Vachellia.
} 
TABELA 2 - Abundância, Dominância, Frequência e Índice de Valor de Importância das espécies arbóreas do Algarrobal.

\begin{tabular}{|c|c|c|c|c|c|c|c|}
\hline \multirow{2}{*}{ Espécies } & \multicolumn{2}{|c|}{ Abundância } & \multicolumn{2}{|c|}{ Dominância } & \multicolumn{2}{|c|}{ Frequência } & \multirow{2}{*}{ IVI } \\
\hline & $\mathbf{N}^{\circ}$ & $\%$ & $\mathbf{m}^{2}$ & $\%$ & ABS & $\%$ & \\
\hline Acacia caven & 87 & 25,66 & 988,2963 & 16,65 & 42 & 16,87 & 19,73 \\
\hline Aspidosperma quebrachoblanco & 80 & 23,60 & 850,5017 & 14,32 & 58 & 23,30 & 20,41 \\
\hline Chrysophyllum marginatum & 3 & 0,89 & 28,2960 & 0,48 & 8 & 3,21 & 1,52 \\
\hline Guettarda uruguensis & 3 & 0,89 & 42,9417 & 0,72 & 8 & 3,21 & 1,61 \\
\hline Parkinsonia aculeata & 17 & 5,01 & 504,3793 & 8,50 & 8 & 3,21 & 5,57 \\
\hline Prosopis affinis & 23 & 6,78 & 390,5340 & 6,58 & 25 & 10,04 & 7,80 \\
\hline Prosopis nigra & 107 & 31,56 & 3002,1663 & 50,57 & 67 & 26,91 & 36,35 \\
\hline Sebastiania brasiliensis & 3 & 0,89 & 7,7903 & 0,13 & 8 & 3,21 & 1,41 \\
\hline Scutia buxifolia & 13 & 3,83 & 110,9950 & 1,87 & 17 & 6,83 & 4,18 \\
\hline Xylosma venosum & 3 & 0,89 & 10,7353 & 0,18 & 8 & 3,21 & 1,42 \\
\hline TOTAL & 339 & 100 & 5936,6559 & 100 & 249 & 100 & 100 \\
\hline
\end{tabular}

$\mathrm{N}^{\circ}=$ número; $\mathrm{ABS}=$ valor absoluto; $\mathrm{IVI}=$ Índice de Valor de Importância.

Fonte: MARCHIORI, LONGHI \& GALVÃO, 1985b. Op. cit., p. 156.

Os dados de Galvani encontram suporte, tanto no restante da literatura como na realidade local, que pode ser aquilatada, facilmente, mesmo em rápida visita ao "Parque Estadual do Espinilho". A mesma coisa não se pode dizer do publicado no "Inventário Florestal Contínuo do Rio Grande do Sul", com seus dados numéricos absolutamente irreais. Alguma luz nesta controvérsia, felizmente, pode ser buscada, ainda, em modesta publicação de 1985, anteriormente lembrada: a primeira descrição feita, no Rio Grande do Sul, sobre o Algarrobal.

Em 1985, Marchiori, Longhi \& Galvão publicaram os primeiros estudos fitossociológicos sobre os parques de Barra do Quaraí - e, justamente, em artigos separados -, vale repetir, por reconhecerem duas tipologias distintas na região. No estudo sobre a "Associação natural de Parque Inhanduvá com Quebracho e Cina- cina" ${ }^{37}$, os dados obtidos aproximam-se, razoavelmente, dos encontrados pelo "Inventário Florestal Contínuo". De 339 indivíduos mensurados, 107 foram de Prosopis nigra, 87 de Vachellia caven $^{38}$, 80 de Aspidosperma quebrachoblanco, 23 de Prosopis affinis e 17 de

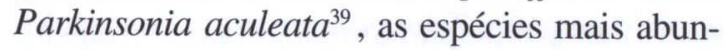
dantes na vegetação do Algarrobal (Tabela 2).

Tanto os dados de Marchiori et al. (1985b), constantes na Tabela 2, como os publicados no "Inventário Florestal Contínuo" (Tabela 1), indicam Prosopis nigra e Vachellia caven ${ }^{40}$ como

\footnotetext{
${ }^{37}$ MARCHIORI, LONGHI \& GALVÃO, 1985b. Op. cit., p. $147-162$.

${ }^{38}$ Acacia caven, no texto original, binômio atualmente reduzido à sinonímia.

${ }^{39}$ MARCHIORI, LONGHI \& GALVÃO, 1985b. Op. cit., p. 156.

${ }^{40}$ Usa-se, aqui, o binômio atualmente válido, uma vez que
} 
espécies predominantes. Seria o caso, então, do "Inventário Florestal Contínuo" ter concentrado seus esforços de campo no levantamento de amostras em área de Algarrobal? Tudo leva a crer que sim, uma vez que Prosopis nigra, a espécie com maior número de árvores por hectare segundo o "Relatório Final", encontra-se, tão somente, nesta tipologia de parque.

Vale frisar que o Algarrobal ocupa área relativamente pequena na Unidade de Conservação em análise. Além do inhanduvá (Prosopis affinis) e do espinilho (Vachellia caven), espécies predominantes no Ñandubaysal, bem como da taleira (Celtis ehrenbergiana), do garupá (Aloysia gratissima), da coronilha (Scutia buxifolia), do molho (Schinus polygamus), da sombra-de-touro (Acanthosyris spinescens) e do curupi (Sapium haematospermum), espécies igualmente ali encontradas, embora com presença menos conspícua e modestos índices fitossociológicos, o Algarrobal se distingue do Ñandubaysal, justamente pela predominância do algarrobo (Prosopis nigra) e as presenças inconfundíveis do quebracho (Aspidosperma quebrachoblanco) e da cina-cina (Parkinsonia aculeata) na estrutura de sua vegetação. Esta tipologia está associada a relevo ainda mais plano do que o verificado no Nandubaysal e apresenta manchas circulares de solo também mais alcalino e com elevados teores de sódio solúvel, responsável pela ausência ou rarefação do estrato herbáceo nas referidas manchas, onde somente habitam espécies muito tolerantes, como o pequeno Tripogon spicatus (Poaceae) $\mathrm{e}$ Gymnocalycium schroederianum ${ }^{41}$ (Cactaceae), além do algarrobo (Prosopis nigra) e quebracho (Aspidosperma quebrachoblanco), entre outras espécies características.

Acacia caven, nome científico utilizado em ambos os trabalhos citados, recaiu em sinonímia.

${ }^{41}$ Espécie halófila, recentemente encontrada por Anabela Silveira de Oliveira Deble no Parque Estadual do Espinilho (DEBLE, A.S. de O. A família Cactaceae Juss. no Bioma Pampa. Checklist, distribuição geográfica e status de conservação. In: DEBLE, L.P.; DEBLE, A.S. de O.; LEÃO, A.L.S. O Bioma Pampa: Contribuições científicas. Bagé: Ediurcamp, 2011. p. 57).
O Algarrobal, em suma, é muito distinto do Ñandubaysal, a tipologia predominante na área do "Parque Estadual do Espinilho", tanto por sua composição florística, como pelas características do solo, que é marcado, fisionomicamente, pelas referidas manchas circulares, ditas Blanqueales na literatura uruguai $^{42}$ e argentina.

Esta tipologia (Algarrobal), vale repetir, apresenta área relativamente pequena no "Parque Estadual do Espinilho", tanto que o quebracho (Aspidosperma quebrachoblanco) e o verdadeiro algarrobo (Prosopis nigra) nem foram conhecidos por Balduíno Rambo em sua visita a Barra do Quaraí, no início da década de 1940.

Sob o ponto de vista fisionômico, o Algarrobal é mais "atrativo" a olhos acostumados a florestas, sobretudo pelo quebracho, que é a espécie de maior altura e com troncos mais robustos em toda a vegetação de parque, na Unidade de Conservação em foco. Seria este, por acaso, o motivo desta tipologia ter sido considerada como representativa dos "estágios sucessionais médio e avançado" na "Região do Parque Espinilho"? Se assim o foi, tem-se outro ledo (e grave) engano.

$\mathrm{O}$ parque de inhanduvá propriamente dito (Ñandubaysal) e o parque com algarrobo e quebracho (Algarrobal) não constituem estágios sucessionais, mas duas comunidades muito distintas entre si, como visto anteriormente, seja pela composição florística ou por peculiaridades edáficas envolvidas.

A concentração da amostragem realizada pelo "Inventário Florestal Contínuo do Rio Grande do Sul" na "Região do Parque Espinilho" em área de Algarrobal ${ }^{43}$, ou sua li-

${ }^{42}$ Em sua descrição do quebracho (Aspidosperma quebrachoblanco) e do algarrobo (Prosopis nigra), BRUSSA \& GRELA (2007) informam que ambas as espécies habitam "bosques de parque en planicies del oeste, en blanqueales de suelos alcalinos" (Op. cit., p. 314 e 418 , respectivamente). É significativo que os mesmos autores, ao se referirem ao inhanduvá (Prosopis affinis), indicam sua ocorrência, apenas, em "bosques de planícies del oeste" (Op. cit., p. 418).

${ }^{43}$ Como visto anteriormente, esta é a única explicação possível para a "estranha" novidade "científica" 
mitação a esta tipologia (como saber?), constitui, de todo modo, erro primário - e da maior gravidade em se tratando de Inventário Florestal -, pois fere, irretorquivelmente, um princípio basilar deste autêntico rebento da Estatística: a amostra precisa ser representativa da população.

Se na tabela comentada, com seus dados básicos sobre a vegetação em estudo, se encontram apenas irrealidades, cabe perguntar-se que valor pode ter, ou que credibilidade merecem os demais dados numéricos que abundam na sequiência. $\mathrm{O}$ eventual leitor interessado em conhecer um pouco, sequer, sobre a "Região do Parque Espinilho", terá de garimpar em demasiado cascalho - e com escassa garantia de algum sucesso-, no documento produzido pelos escribas do "Inventário Florestal Contínuo do Rio Grande do Sul". Como descobrir alguma eventual semente de trigo em meio a tanto joio?

Com toda a certeza, apesar das indicações constantes no documento em análise, não se realizou, verdadeiramente, um inventário digno do nome (para dizer o mínimo), sobre o elemento arbóreo na "Região do Parque Espinilho". Com toda certeza, ainda, pode-se afirmar que o texto relativo a esta tipologia no "Inventário Florestal Contínuo do Rio Grande do Sul" representa um desserviço à Ciência, pela carga de erros primários que encerra, além de não acrescentar uma letra, sequer, ao conhecimento desta vegetação singular, que é, vale salientar, uma das mais elementares sob o ponto de vista florístico, em todo o estado sulino. Os disparates cometidos não se limitam, todavia, ao texto da "Região do Parque Espinilho".

publicada no "Inventário Florestal Contínuo do Rio Grande do Sul": o algarrobo (Prosopis nigra), com 63,2 árvores por hectare é, de longe, a espécie mais encontradiça na "Região do Parque Espinilho", seguida pelo inhanduvá, com valor pouco maior do que a metade (35,6 árvores/hectare) do verificado para a outra espécie de Prosopis! Como os autores deste disparate não se deram conta de tamanha irrealidade? O papel aceita tudo... !

${ }^{44} \mathrm{O}$ texto se encontra entre as páginas 466 e 475 , do "Relatório Final do Inventário Florestal Contínuo do RS".
Ao tratar da "Bacia Hidrográfica do Quarấ”"44, o algarrobo (Prosopis nigra) figura como a quarta espécie arbórea com maior número de árvores por hectare $(28,73)$, superado neste quesito apenas por Sebastiania commersoniana (156,37 árvores/ha), Lithraea molleoides $(106,46)$, Schinus lentiscifolius $(82,73)$ e "árvores mortas" $(44,09)^{45}$. O inhanduvá (Prosopis affinis), como no texto relativo à "Região do Parque Espinilho", mantémse com valor pouco superior à metade $(16,19$ árvores/ha) do referido para Prosopis nigra (Tabela 3). Teriam sido os dados simplesmente "transplantados" da "Região do Parque Espinilho" para a Bacia Hidrográfica do rio Quaraí como um todo?

O absurdo cresce exponencialmente, se este foi o caso, uma vez que implica erro geográfico primário, detectável com o simples exame de um mapa: o "Parque Estadual do Espinilho", única área com remanescentes expressivos dos parques de inhanduvá na região do Pontal, se encontra integralmente, em verdade, na bacia do Quaraí-Chico, que é paralela à do rio Quaraí (Figura 3). O modesto Arroio Quaraí-Chico, em outras palavras, é tão afluente do rio Uruguai como o extenso rio Quaraí, que nasce próximo a Santana do Livramento e constitui, ao longo de todo o seu curso, em divisa natural do Brasil com a República Oriental do Uruguai ${ }^{46}$.

Os dados relativos à "Bacia Hidrográfica do Rio Quaraî", por sua vez, conseguem a proeza de serem ainda mais irreais, senão fantasiosos, do que os apresentados no capítulo anteriormente examinado. Ninguém precisa circular ao longo deste rio, tarefa cansativa e cara, para comprovar o absurdo dos números apresentados. Basta examinar a região pelo Google Earth, no conforto de seu gabinete, em casa, de preferência em sua poltrona preferida. Como alternati-

\footnotetext{
${ }^{45}$ RIO GRANDE DO SUL, 2001. Op. cit., p. 467.

${ }^{46} \mathrm{O}$ rio Quaraí nasce da confluência dos arroios Maneco e Invernada, separados entre si por uma área relativamente pequena e de forma triangular, cuja posse é contestada pelos dois países vizinhos.
} 


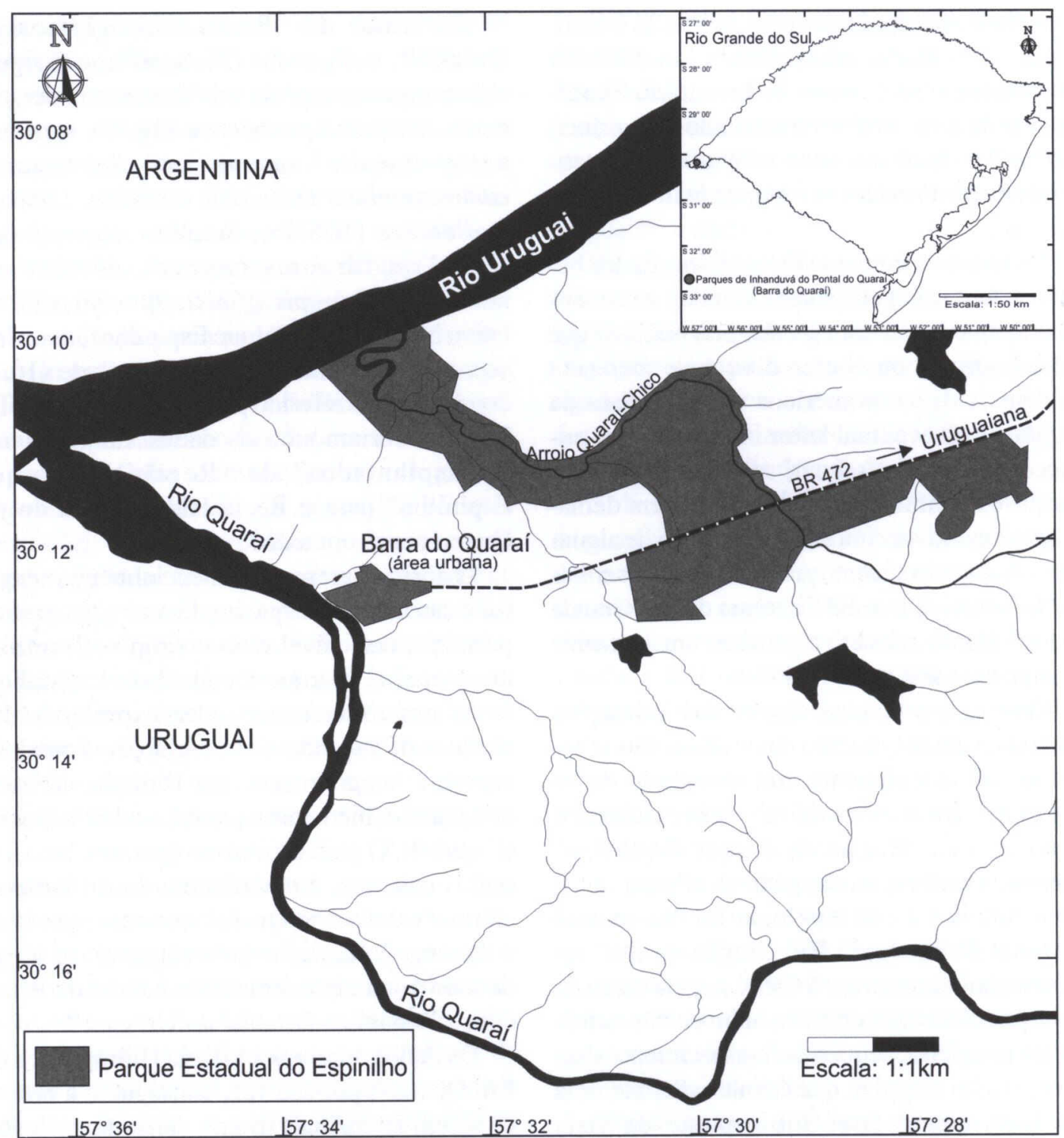

FIGURA 3 - Mapa de localização do "Parque Estadual do Espinilho", no Pontal do Quaraí.

va, apresentamos o mapa constante na Figura 4 , pois ele é muito esclarecedor.

O disparate nos valores numéricos e espécies discriminadas na referida tabela é de pasmar, tal a sua incompatibilidade com a realidade vegetacional na bacia do rio Quaraí e as exigências ecológicas das distintas espécies.

A única região propícia à ocorrência natural dos parques anteriormente analisados (Ñandubaysal e Algarrobal), em área significativa, está no Pontal do Quaraí: a extensa região aplanada e natureza sedimentar, situada no cotovelo formado pelos rios Quaraí e Uruguai. A situação fundiária e a vegetação nesta região podem ser facilmente apreendidos em rápido exame visual, na tela do computador: como área extremamente favorável ao cultivo do arroz, quase toda a região do Pontal se encontra ocupada, há décadas, por lavouras deste cereal, além da área urbana de Barra do Quaraí, ressalvada, 


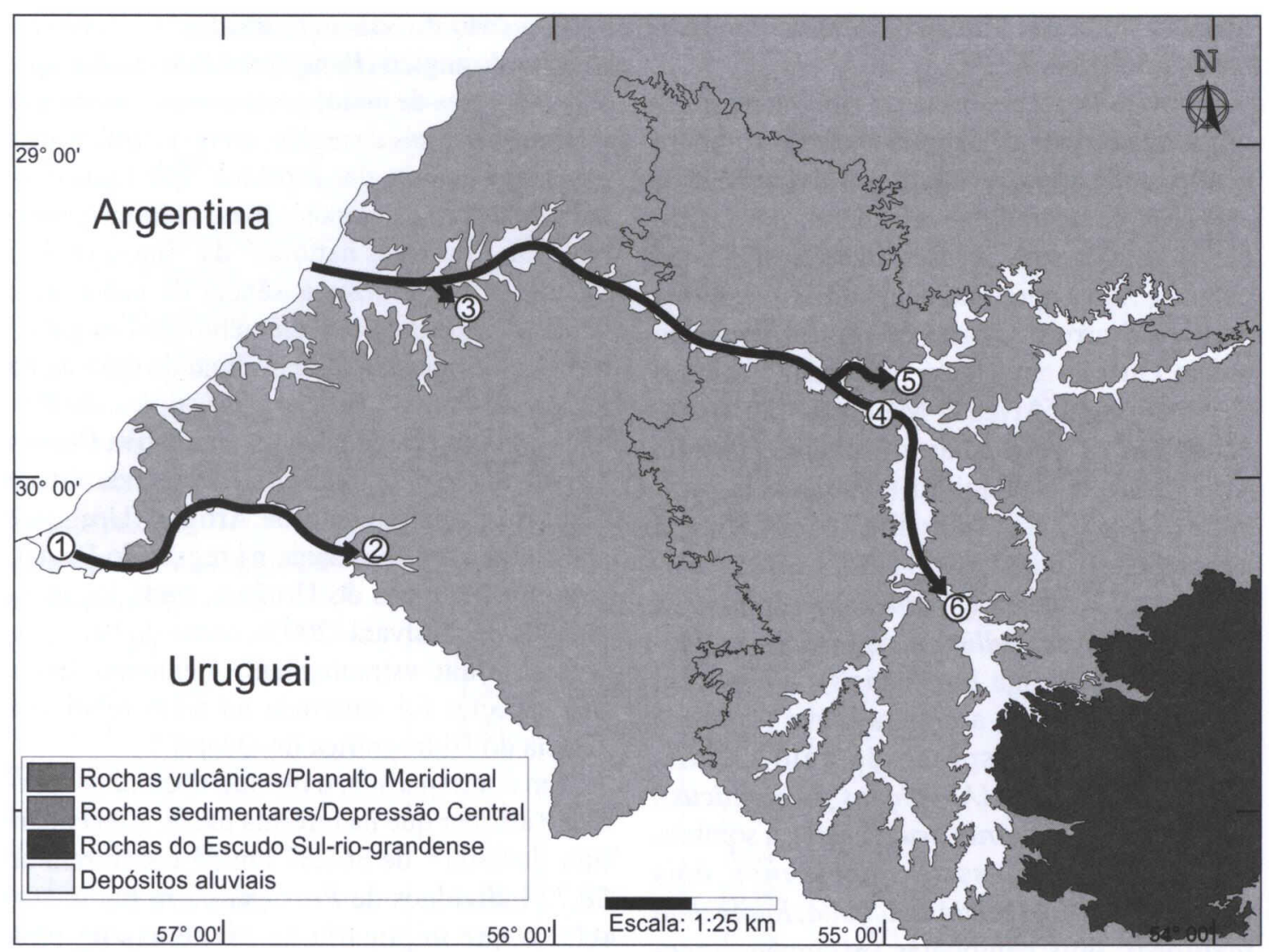

FIGURA 4 - Rotas imigratórias do inhanduvá em mapa geológico e geomorfológico simplificado do centro-oeste do Rio Grande do Sul, mostrando a associação dos seis parques com depósitos sedimentares. 1 - Parques de inhanduvá do Pontal do Quaraí. 2 - Parque de inhanduvá do Jarau. 3 - Parque de inhanduvá do Itapororó. 4 - Parque de inhanduvá de Cacequi. 5 - Parque de inhanduvá do Loreto. 6-Parque de inhanduvá de Rosário do Sul. Fonte base do mapa: BRASIL. Ministério de Minas e Energia. Companhia de Pesquisa de Recursos Minerais (CPRM). Serviço Geológico do Brasil. Mapa Geológico do Estado do Rio Grande do Sul (Escala 1:750.000). Porto Alegre, 2008.

neste conjunto, a área correspondente ao "Parque Estadual do Espinilho".

Fora do Pontal, o rio Quaraí, por estar “entalhado em derrame basáltico" ${ }^{47}$, proporciona escassas e estreitas planícies aluviais, formação indispensável à ocorrência natural do inhanduvá (Prosopis affinis). No caso do algarrobo (Pro-

${ }^{47}$ Usou-se, aqui, a mesma expressão anteriormente criticada, por a terem utilizado os autores do "Relatório Final do Inventário Florestal Contínuo do Rio Grande do Sul" na caracterização geomorfológica da "Região do Parque Espinilho". Se inapropriada naquela situação, uma vez que a área do Pontal não se encontra "entalhada" no basalto, a expressão serve como luva para a maior parte do rio Quaraí, ao atravessar o "Planalto da Campanha". sopis nigra), espécie indicada no "Relatório Final" como ainda mais abundante do que o inhanduvá na bacia do rio Quaraí, pode-se afirmar, cabalmente, que este absurdo contradiz toda a literatura existente.

Prosopis nigra é espécie associada aos blanqueales e, no Rio Grande do Sul, restrita, pelo que se sabe até o momento, aos arredores da cidade de Barra do Quaraí. Como pode, então, Prosopis nigra ser a quarta espécie arbórea com maior número de indivíduos por hectare na bacia do rio Quaraí? Os exemplares desta espécie, porventura ainda existentes nesta bacia, podem ser contados, muito provavelmente, nos dedos de uma única mão, ou pouco mais do 
que isso. Tamanho absurdo, nem merece maiores comentários.

Fora do Pontal, a bacia do rio Quaraí apresenta mata ciliar de largura variável, embora geralmente estreita, e com pouca diversidade de espécies, comparada ao rio Ibicuí, por exemplo. A lista de suas árvores, todavia, não é tão exígua como a apresentada no dito Inventário.

Para o arroio Quaraí-Mirim, afluente do médio Quaraí, em região próxima ao famoso Cerro do Jarau, Alves \& Marchiori (2010) encontraram na mata ciliar: o sarandi (Pouteria salicifolia), o branquilho (Sebastiania commersoniana), o amarilho (Sebastiania schottiana), o salso-crioulo (Salix humboldtiana), o sucará (Gleditsia amorphoides), o aguaí (Chrysophyllum marginatum), o pauleiteiro (Sebastiania brasiliensis), o chal-chal (Allophylus edulis), a aroeira-brava (Lithraea molleoides), o esporão-de-galo (Celtis iguanaea), o vacum (Allophylus guaraniticus), o veludinho (Guettarda uruguensis), a sombrade-touro (Acanthosyris spinescens), dois marmeleiros (Ruprechtia salicifolia, Ruprechtia laxiflora), dois camboatás (Matayba elaeagnoides, Cupania vernalis), o topete-de-cardeal (Calliandra tweediei), bem como algumas capororocas (Myrsine lorentziana, Myrsine laetevirens), canelas (Nectandra megapotamica, Nectandra angustifolia, Ocotea acutifolia) e Mirtáceas (Blepharocalyx salicifolius, Eugenia uniflora, Myrcia selloi, Myrcianthes cisplatensis, Myrcianthes gigantea, Myrcianthes pungens, Myrrhinium atropurpureum). De maior valor econômico, os mesmos autores referem, ainda, a presença conspícua do angico-vermelho (Parapiptadenia rigida), da guajuvira (Cordia americana) e do açoita-cavalo (Luehea divaricata $)^{48}$. Na periferia para o campo limpo, como regra, encontra-se um parque ralo de espinilhos (Vachellia caven), mas não o inhanduvá, espécie sabidamente vinculada a formações sedimentares.

\footnotetext{
48 ALVES \& MARCHIORI, 2010. Op. cit., p. 7.
}

E o caso do salso-crioulo (Salix humboldtiana) e do angico (Parapiptadenia rigida), que são as árvores de maior porte e mais conspícuas nas matas ciliares da região, como justificar suas ausências na lista das espécies "que mais contribuíram para a composição do volume comercial" nas "florestas naturais" da "Bacia do Rio Quaraí"? E que dizer ausência da canafístula (Peltophorum dubium), elemento tão conspícuo na mata associada ao trecho final do Quaraí, na região do Pontal? Esta espécie, típica da Floresta do Alto Uruguai e com chamativa florada estival, desce pela mata ciliar do grande rio até o sul do Departamento de Artigas (Uruguai), chegando a ser abundante na região do Pontal, tanto nas margens do Uruguai, onde foi reconhecida por Galvani (2003), como do baixo rio Quaraí. Muito estranhamente, nenhuma destas três espécies foi lembrada no texto relativo à "Bacia do Hidrográfica do Quaraî".

Em contrapartida, o mesmo documento pretende afirmar que na referida bacia, com cobertura florestal ${ }^{49}$ de $368,87 \mathrm{~km}^{2}$, 50 encontram-se 28,73 indivíduos de Prosopis nigra por hecta$\mathrm{re}^{51}$, o que implicaria na existência de uma extensíssima savana desta espécie arbórea que é, sabidamente, uma das árvores mais raras no Rio Grande do Sul ${ }^{52}$. Deixa-se ao leitor interessado a execução deste elementar cálculo matemático; maior absurdo não se pode conceber!

Não é preciso entender-se de inventário, muito menos enveredar pelas tabelas e núme-

${ }^{49}$ Nos seus "estágios iniciais, médios e avançados", para ser ainda mais literal.

${ }^{50}$ RIO GRANDE DO SUL, 2001. Op. cit., p. 466.

${ }^{51}$ RIO GRANDE DO SUL, 2001. Op. cit., p. 467.

${ }^{52}$ Muito provavelmente já estaria extinta em solo gaúcho, não fosse a providencial criação do "Parque Estadual do Espinilho". Não custa repetir que a área do "Parque Estadual do Espinilho" se encontra na Bacia do Rio Quaraí-Chico, paralela à do Rio Quaraí. Onde estariam, então, os algarrobos da Bacia do Quaraí? Eles não mais existem, praticamente, ao contrário do afirmado no "Relatório Final". Trata-se de erro grosseiro, próprio de quem não conhece a realidade local. $\mathrm{O}$ algarrobo é elemento notavelmente mais raro e ameaçado de extinção do que o próprio inhanduvá no RS, pois sua ocorrência, ao que se sabe, limitava-se, originalmente, a pequenas manchas (Blanqueales), no Pontal do Quaraí. 
TABELA 3 - Espécies que mais contribuem para o volume comercial e árvores mortas nas florestas naturais da Bacia Hidrográfica do Rio Quaraí.

\begin{tabular}{|c|c|c|c|c|c|c|}
\hline \multirow{3}{*}{$\begin{array}{c}\text { Espécie } \\
\text { Lithraea molleoides }\end{array}$} & \multicolumn{2}{|c|}{ Vol. Comercial } & \multicolumn{2}{|c|}{$N^{o}$ Árvores } & \multicolumn{2}{|c|}{ Área Basal } \\
\hline & \multicolumn{2}{|l|}{$\left(\mathrm{m}^{3} / \mathrm{ha}\right)$} & \multicolumn{2}{|l|}{ (N\%/ha) } & $\left(\mathrm{m}^{2} / \mathrm{ha}\right)$ & \\
\hline & 14,80 & 21,39 & 106,46 & 17,18 & 3,0 & 21,55 \\
\hline Schinus lentiscifolius & 11,69 & 16,89 & 82,73 & 13,35 & 2,25 & 16,16 \\
\hline Sebastiania commersoniana & 10,48 & 15,14 & 156,37 & 25,24 & 1,87 & 13,43 \\
\hline Mortas & 5,80 & 8,38 & 44,09 & 7,12 & 0,89 & 6,39 \\
\hline Prosopis nigra & 2,83 & 4,09 & 28,73 & 4,64 & 0,68 & 4,89 \\
\hline Erythrina cristagalli & 2,48 & 3,58 & 3,64 & 0,59 & 0,70 & 5,03 \\
\hline Styrax leprosus & 2,24 & 3,24 & 20,00 & 3,23 & 0,40 & 2,87 \\
\hline Myrrhinium atropurpureum & 1,84 & 2,66 & 12,73 & 2,05 & 0,46 & 3,30 \\
\hline Prosopis affinis & 1,82 & 2,63 & 16,19 & 2,61 & 0,42 & 3,02 \\
\hline Acacia caven & 1,61 & 2,33 & 27,27 & 4,40 & 0,33 & 2,37 \\
\hline Schinus polygamus & 1,51 & 2,18 & 11,82 & 1,91 & 0,35 & 2,51 \\
\hline Schinus molle & 1,41 & 2,04 & 2,13 & 0,34 & 0,30 & 2,16 \\
\hline Myrcianthes pungens & 1,06 & 1,53 & 5,46 & 0,88 & 0,23 & 1,65 \\
\hline Scutia buxifolia & 1,03 & 1,49 & 13,82 & 2,23 & 0,20 & 1,44 \\
\hline Myrsine laetevirens & 1,00 & 1,45 & 3,64 & 0,59 & 0,25 & 1,80 \\
\hline Parkinsonia aculeata & 0,99 & 1,43 & 10,00 & 1,61 & 0,22 & 1,58 \\
\hline Celtis spinosa & 0,83 & 1,20 & 6,36 & 1,03 & 0,15 & 1,08 \\
\hline Pouteria gardneriana & 0,72 & 1,04 & 6,36 & 1,03 & 0,14 & 1,01 \\
\hline Myrcianthes cisplatensis & 0,64 & 0,92 & 11,09 & 1,79 & 0,13 & 0,93 \\
\hline Aspidosperma quebrachoblanco & 0,58 & 0,84 & 2,72 & 0,44 & 0,12 & 0,86 \\
\hline Sub-total & 65,36 & 94,45 & 571,61 & 92,25 & 13,09 & 94,04 \\
\hline Restantes & 3,84 & 5,55 & 48,03 & 7,75 & 0,83 & 5,96 \\
\hline TOTAL & 69,20 & 100,00 & 619,64 & 100,00 & 13,92 & 100,00 \\
\hline
\end{tabular}

Fonte: RIO GRANDE DO SUL, 2001. Op. cit., p. 467.

ros apresentados para a "Bacia Hidrográfica do Quaraî”, para se chegar à conclusão de que este capítulo também não oferece uma pálida imagem, sequer, da realidade que ali existe. Pretender que Prosopis nigra e Prosopis affinis estejam entre as árvores mais freqüentes na Bacia do Rio Quaraí, como afirmado em dados constantes no relatório, é um disparate que compromete, definitivamente, a credibilidade do trabalho realizado.
Por falar em trabalho, não faltaram recursos materiais e humanos para a execução do "Inventário Florestal Contínuo do Rio Grande do Sul", fato sobejamente demonstrado nas páginas iniciais do "Relatório Final". Os erros crassos presentemente apontados colocam em situação contrangedora todo o texto publicado, por distanciar-se, quase sideralmente, da realidade vegetacional encontrada, tanto na "Região do Parque Espinilho" como na "Bacia Hidrográfica do Quaraî". 
E como se explica o fato da numerosa equipe que esquadrinhou o interior do Estado em trabalhos de levantamento da vegetação nativa não ter encontrado outros parques de inhanduvá no Rio Grande do Sul, se eles lá estão e deles já se falava desde 1983 ? O aludido trabalho científico foi consultado ${ }^{53}$, como indica a lista bibliográfica, à página 704 do "Relatório Final". Como se vê, o "Inventário Florestal Contínuo do Rio Grande do Sul" perdeu a oportunidade ímpar de contribuir, de modo substancial, ao real conhecimento dos parques de inhanduvá no Rio Grande do Sul, antecipando, em cerca de 10 anos, informações preciosas sobre esta espécie merecedora, justamente, de proteção legal.

Nos últimos 12 meses, em contraste - sem qualquer apoio e com recursos próprios -, os autores da presente análise crítica brindaram, à Ciência e ao povo do Rio Grande do Sul, novidades que constituem uma verdadeira revolução no conhecimento sobre os parques de inhanduvá no Estado, comprovando, definitivamente, novas áreas de ocorrência da espécie: na região do Jarau, município de Quaraí (Alves \& Marchiori, 2010); nas cercanias do Cerro do Loreto, em São Vicente do Sul (Marchiori et al., 2010); na várzea do rio Santa Maria, em Rosário do Sul (Alves \& Marchiori, 2011a); na várzea do rio Ibicuí, município de Cacequi (Marchiori \& Alves, 2011a); e na várzea do arroio Itapororó, em Alegrete (Alves \& Marchiori, 2011b). A comprovação do estreito vínculo do inhanduvá com formações sedimentares, a barreira proporcionada pelos basaltos da Formação Serra Geral na expansão da espécie, em direção ao centro do Estado, e as rotas imigratórias por ela seguidas, ao longo do vale dos rios Quaraí e Ibicuí (Figura 4), são temas igualmente esclarecidos nos últimos meses, em trabalho de cunho fitogeográfico (Marchiori \& Alves, 2011b).

Foi com a expectativa de encontrar alguma informação nova sobre a Província do Espinhal no Rio Grande do Sul, pesquisa ainda em anda-

${ }^{53}$ MARCHIORI, LONGHI \& GALVÃO, 1983. Op. cit., p. 173. mento, que os autores do presente trabalho tiveram acesso ao texto do "Inventário Florestal Contínuo do Rio Grande do Sul”, graças à tradicional gentileza e amabilidade de Solon Jonas Longhi, colega e amigo de longa data. A ele, portanto, os nossos sinceros agradecimentos pela oportunidade de apontar, à comunidade científica, a volumosa carga de incongruências existente nos textos do "Inventário Florestal Contínuo do Rio Grande do Sul", relativos à "Região do Parque Espinilho" e à "Bacia Hidrográfica do rio Quaraî".

\section{REFERÊNCIAS BIBLIOGRÁFICAS}

ALVES, F. da S.; MARCHIORI, J.N.C. O inhanduvá (Prosopis affinis Spreng.) no Rio Grande do Sul. 2 - Ocorrência natural na região do Jarau, Quaraí. Balduinia, Santa Maria, n. 25, p. 1-9, 2010.

ALVES, F. da S.; MARCHIORI, J.N.C. O inhanduvá (Prosopis affinis Spreng.) no Rio Grande do Sul. 5 - Ocorrência natural na várzea do rio Santa Maria, Rosário do Sul. Balduinia, Santa Maria, n. 27, p. 1-7, 2011a.

ALVES, F. da S.; MARCHIORI, J.N.C. O inhanduvá (Prosopis affinis Spreng.) no Rio Grande do Sul. 7 - Ocorrência natural na planície de inundação do Arroio Itapororó, município de Alegrete. Balduinia, Santa Maria, n. 28, p. 1-7, 2011 b.

CABRERA, A.L. Territórios fitogeográficos de la Republica Argentina. Boletín de la Sociedad Argentina de Botánica, v. 4, n. 1-2, p. 21-65, 1951.

BRUSSA SANTANDER, C.A.; GRELA GONZÁLEZ, I.A. Flora arbórea del Uruguay. Con énfasis en las especies de Rivera y Tacuarembó. Montevideo: Cofusa, 2007. 542 p.

DEBLE, A.S. de O. A família Cactaceae Juss. no Bioma Pampa. Checklist, distribuição geográfica e status de conservação. In: DEBLE, L.P.; DEBLE, A.S. de O.; LEÃO, A.L. S. O Bioma Pampa. Contribuições científicas. Bagé: Ediurcamp, 2011. p. 43-71.

GALVANI, F.R. Vegetação e aspectos ecológicos do Parque Estadual do Espinilho, Barra do Quaraí, $R S$. Porto Alegre: Universidade Federal do Rio Grande do Sul, 2003. 132 f. Tese de Doutorado (Programa de Pós-Graduação em Botânica). 
GALVANI, F.R.; BAPTISTA, L.R. de M. Flora do Parque Estadual do Espinilho - Barra do Quaraí, RS. Revista da FZVA, Uruguaiana, v. 10, n. 1, p. 42-62, 2003.

IZAGUIRRE, P.; BEYAHUT, R. Las Leguminosas en Uruguay y regiones vecinas. Montevideo: Editorial Hemisferio Sur, 2003. 301 p.

JUSTUS, J. de O.; MACHADO, M.L. de A.; FRANCO, M. do S.M. Geomorfologia. In: IBGE. Folha SH.22 Porto Alegre e parte das folhas SH.21 Uruguaiana e SI.22 Lagoa Mirim. Levantamento de Recursos Naturais. Rio de Janeiro: Fundação Instituto Brasileiro de Geografia e Estatística, 1986. v. 33. p. 313-404.

LINDMAN, C.A.M. A vegetação no Rio Grande do Sul (Brasil Austral). Porto Alegre: Echenique, 1906. 356 p.

MARCHIORI, J.N.C.; ALVES, F. da S. O Inhanduvá (Prosopis affinis Spreng.) no Rio Grande do Sul. 1 - Embasamento fitogeográfico e pendências terminológicas. Balduinia, Santa Maria, n. 24, p. 1-11, 2010.

MARCHIORI, J.N.C.; ALVES, F. da S. O inhanduvá (Prosopis affinis Spreng.) no Rio Grande do Sul. 6 - Descrição de um parque natural na várzea do rio Ibicuí, município de Cacequi. Balduinia, Santa Maria, n. 27, p. 8-14, 2011a.

MARCHIORI, J.N.C.; ALVES, F. da S. O inhanduvá (Prosopis affinis Spreng.) no Rio Grande do Sul. 8 - Aspectos fitogeográficos. Balduinia, Santa Maria, n. 29, p. 13-20, 2011 b.

MARCHIORI, J.N.C.; ALVES, F. da S.; PAZ, E.A. O inhanduvá (Prosopis affinis Spreng.) no Rio
Grande do Sul. 3 - Parque da Cabanha do Loreto, São Vicente do Sul. Balduinia, Santa Maria, n. 25, p. 22-31, 2010.

MARCHIORI, J.N.C.; LONGHI, S.J.; GALVÃO, L. O gênero Prosopis L. (Leguminosae Mimosoideae) no Rio Grande do Sul. Ciência e Natura, Santa Maria, n. 5, p. 171-177, 1983.

MARCHIORI, J.N.C.; LONGHI, S.J.; GALVÃO, L. Composição florística e estrutura do Parque de Inhanduvá no Rio Grande do Sul. Rev. Centro de Ciências Rurais, Santa Maria, v. 15, n. 4, p. 319-334, 1985a.

MARCHIORI, J.N.C.; LONGHI, S.J.; GALVÃO, L. Estrutura fitossociológica de uma associação natural de Parque Inhanduvá com quebracho e cina-cina, no Rio Grande do Sul. Ciência e Natura, Santa Maria, n. 7, p. 147-162, 1985b.

PAZ, E.A.; BASSAGODA, M.J. Aspectos fitogeográficos y diversidad biológica de las formaciones boscosas del Uruguay. Ciência \& Ambiente, Santa Maria, n. 24, p. 35-50, 2002.

PÉLLICO NETO, S.; BRENA, D.A. Inventário Florestal. Curitiba: Editorado pelos autores, 1997. 316 p.

RAMBO, B. A fisionomia do Rio Grande do Sul. Porto Alegre: Livraria Selbach, 1956. 456 p.

REITZ, R.; KLEIN, R.M.; REIS, A. Projeto Madeira do Rio Grande do Sul. Sellowia, Itajaí, 1983. p. 1-525.

RIO GRANDE DO SUL. Governo do Estado. Secretaria Estadual do Meio Ambiente. Inventário Florestal Contínuo do Rio Grande do Sul. Porto Alegre: SEMA/FATEC, 2001. 706p. 